DOI https://doi.org/10.30525/978-9934-588-79-2-1.9

\title{
ІНФОРМАЦЙНІ ІНТЕЛЕКТУАЛЬНІ СИСТЕМИ КОНТРОЛЮ ЯКОСТІ ПРОДУКЦІЇ
}

\author{
Костюк Ю. В. \\ асистент кафедри інженерї програмного забезпечення \\ та кібербезпеки \\ Київського наџіонального торговельно-економічного університету
}

Криворучко О. В.

доктор технічних наук, професор,

завідувач кафедри інженерії програмного забезпечення

та кібербезпеки

Київського начіонального торговельно-економічного університету

Костюк I. B.

кандидат технічних наук,

керівник відділу автоматизачіi

$T O B « T I C E P »$

м. Київ, Украӥна

В умовах сьогодення автоматизація виробничих процесів, когнетивність інформаційних систем та єдиний інформаційний простір підприємства $є$ невід'ємними складовими успіху будь-якого підприємства. При цьому досить важливим завданням є поєднання існуючих інформаційних систем в єдиний інформаційний простір підприємства, що дозволить забезпечити їх сумісність на рівні даних із можливістю проводити аналіз даних із подальшим прийняттям управлінських рішень. Тому, виникає потреба в отриманні достовірної, оперативної і об'єктивноповної інформації щодо поточної ситуації; забезпеченні доступу фахівців до необхідної їм інформації; можливість попередження щодо виникнення штатних та аварійних ситуацій на виробництві, тощо [1].

Стратегічним напрямком розвитку нового покоління засобів автоматизованого контролю параметрів якості продукції, які не достатньо сформульовані, є використання когнітивних технологій, а саме інтелектуальних систем неперервного контролю якості продукції та прогнозування процесів виробництва.

Складність створення інформаційних інтелектуальних систем задля вирішення задач контролю якості продукції пов'язане з тим, що продукція в деяких випадках є складними та неоднорідними багато- 
компонентними сумішами, які залежать від багатьох факторів: складу сировини, фізико-хімічних властивостей, режимів роботи обладнання, тощо. Тому, побудова інформаційної інтелектуальної системи контролю якості продукції та прогнозування процесів виробництва потребує поєднання технічного, інформаційного та математичного апаратів [1].

Інформаційна інтелектуальна система (IIC) контролю та прогнозування виробничих процесів дозволить вирішити низку задач, а саме контроль в режимі реального часу параметрів технологічного процесу; ідентифікацію поточного стану процесу; прогнозування якості готової продукції; підтримку прийняття рішень в режимі реального часу в залежності від ситуації. Тому, для проектування IIC використовуються індивідуальні експертні оцінки та методи організації колективних експертних систем у визначеній предметній області [2].

Основними компонентами IIC підсистеми контролю якості продукції є: база даних, база знань та підсистема підтримки прийняття рішень. База знань - містить правила виведення та інформацію про досвід людини і знання в деякій предметній області $[3,4]$. Зокрема база знань формується на основі семантичних зв'язків між факторами та правилами знань експертів. База даних виконує функцію тимчасового сховища даних по відповідному технологічному процесу. Підсистема підтримки прийняття рішень містить сформовану цілісну уяву про предмет дослідження та приймає без емоційне рішення, а також поєднує у собі механізм логічного виведення та інтерфейс користувачів рішення, яким прогнозують подальший перебіг подій [2].

Для підсистеми прогнозування IIC якості продукції та прогнозування виробничих процесів використовується апарат нейронних мереж, при побудові якої використовуються накопичені знання відносно деякої предметної області. Формування бази знань відбувається на основі структурно-параметричних, математичних i ситуаційних моделей об'єкта керування. Моделювання системи прогнозування здійснюється шляхом підбору архітектури нейронної мережі та алгоритму навчання.

Структурна інформаційної інтелектуальної системи якості продукції та прогнозування процесів виробництва має конкретні складові (рис. 1).

Отже, IIC якості продукції має складну інформаційну структуру, яка характеризується комплексом програмних засобів, що здатні вирішувати різноманітні задачі на основі обробки знань, давати інтелектуальні поради, приймати рішення на рівні експерта-професіонала, а також за бажанням користувача пояснювати, прогнозувати та регулювати процесом виробництва. 


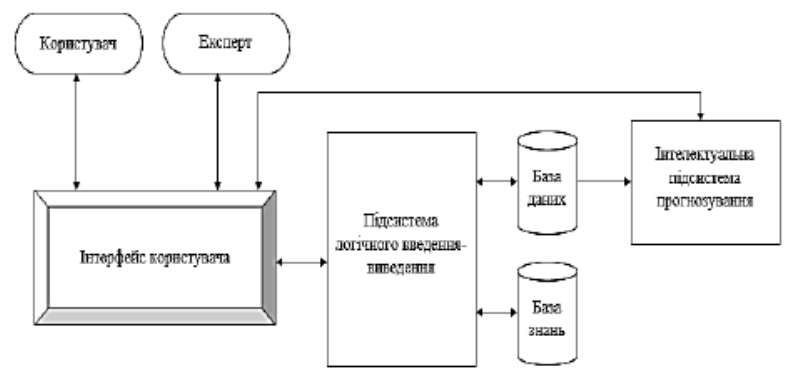

Рис. 1. Структура інформаційної інтелектуальної системи

\title{
Література:
}

1. Бреус Н.М. Інформаційна технологія моделювання морозива: дис. канд. техн. наук: 05.13.06. Київ, 2019. 153 с.

2. Криворучко О.В., Цюцюра С.В. Основи експертних систем: навчальний посібник. Київ: КНТЕУ, 2006. 140 с.

3. ISO/IEC/IEEE 24765:2017. Systems and software engineering Vocabulary.

4. ISO/IEC 2382:2015. Information technology - Vocabulary - Part 1: Fundamental terms.

DOI https://doi.org/10.30525/978-9934-588-79-2-1.10

\section{BIG DATA AND PROTECTION OF INFORMATION FROM LEAKAGE}

\author{
Kokhan V. P. \\ Ph. D, Senior Researcher \\ Scientific \& Research Institute of Providing Legal Framework \\ for the Innovative Development \\ of National Academy of Law Sciences of Ukraine \\ Kharkiv, Ukraine
}

Big Data is structured, unstructured and semi-structured data of huge volumes and diversity, as well as methods of processing them, which allow distributed analysis of information.

In the world of technology, it is common to define Big Data by describing its distinguishing features. Usually three, four or even five properties of 